\title{
SCREENING OF COMPETENT RICE ROOT ENDOPHYTIC BACTERIA TO PROMOTE RICE GROWTH AND BACTERIAL LEAF BLIGHT DISEASE CONTROL
}

\author{
Nur Prihatiningsih ${ }^{1}$, Heru Adi Djatmiko ${ }^{1}, \&$ Puji Lestari ${ }^{2}$ \\ ${ }^{1}$ Faculty of Agriculture, Jenderal Soedirman University, Indonesia \\ ${ }^{2}$ Faculty of Mathematics and Natural Sciences, Jenderal Soedirman University, Indonesia \\ Jl. dr. Suparno Karangwangkal Purwokerto Jawa Tengah 53123 \\ E-mail: prihatiningsihnur@gmail.com
}

Manuscript received: 11 December 2019. Revision accepted: 25 April 2020

\begin{abstract}
Screening of competent rice root endophytic bacteria to promote rice growth and bacterial leaf blight disease control. This study was aimed to collect isolate endophytic bacterial of rice roots which able to produce IAA, determine the effect of endophytic bacteria application in stimulating rice plant growth, and evaluate the potential of rice root endophytic bacteria for controlling bacterial leaf blight. This reasearch was carried out at the Screen House, Plant Protection Laboratory, and Agrohorti Laboratory of the Agriculture Faculty, Jenderal Soedirman University. Isolation of rice root endophytic bacteria was carried out by purposive random sampling from several marginal lands. The results showed that 8 isolates of rice root endophytic bacteria were able to produce IAA, ranging from 57.56 to $79.33 \mathrm{ppm}$ and B07 isolate from Serayu produced the highest amount of IAA. The B04 and B07 isolates were contributed to increase the rice plant growth. The application of rice root endophytic bacteria was effective in controlling bacterial leaf blight.
\end{abstract}

Key words: bacterial leaf blight, endophytic bacteria, IAA, plant growth, rice

\section{INTRODUCTION}

Rice is a staple food for almost all Indonesian. The increase in population causes an increasing in food needs. Therefore, efforts are needed to increase national rice productivity. The need for rice in 2017 reached $111.58 \mathrm{~kg} / \mathrm{capita} / \mathrm{year}$, it was equivalent to 29.13 million tons of rice (BPS, 2019). Thus, improvement in technology is needed to increase the productivity of rice plants that are environmentally friendly and sustainable (Kasno, 2010). The continuous use of chemical fertilizers will cause damage to the physical properties of the soil, the soil becomes denser and phosphate accumulation occurs. Efforts to overcome this problem is using alternative fertilizers that can increase productivity and maintain soil fertility (Havlin et al., 2005).

The application of PGPR (Plant growth-promoting rhizobacteria) is one of the efforts to increase rice productivity, one of which is the utilization of beneficial root endophytic bacteria for plant growth. Endophytic bacteria are bacteria that live and associated with plant tissues without causing any disease to the plant (Spaepen et al., 2007). The presence of endophytic bacteria in plant tissues was not only play a role in improving plant growth but also producing growth promoters, fixing nitrogen, solubilizing phosphate, and playing role in plant health (Wozniak et al., 2019). The N-fixing endophytic bacteria can increase nitrogen fixation from the air. Increasing the concentration of N-fixing endophytic bacteria in biological fertilizer tends to significantly increase plant $\mathrm{N}$ uptake (Setiawati et al., 2002; Mieke, 2008). The superiority of endophytic bacteria as biological control agents, which increase the availability of nutrients, produce growth hormones, control plant diseases, and can induce plant resistance (Kloepper et al., 1992; Hallmann, 2001).

Plants can experience a decrease in productivity caused by endogenous hormones, for example, auxin reduction can cause abnormal growth of plant roots. One of the important auxin group hormone for rice plants is indole acetic acid (IAA). The IAA functions is controlling many important physiological processes including cell enlargement and division, tissue differentiation and response to light and gravity (Khalid et al., 2004). One of the efforts to increase IAA in the paddy fields is through the application of PGPR (Cahyaty et al., 2017). IAA is an endogenous auxin hormone that synthesized in various parts of the plant and generally associated with parts of the plants that actively growing and developing such as in all meristem 
tissues of shoot tips, root tips, and cambium. IAA also stimulates cell extension, regulates apical dominance, and the formation of lateral and adventitious roots (Patil, 2011).

Endophytic bacteria could serve as plant growth promoter and pathogen biocontrol. One important disease in rice plants is bacterial leaf blight caused by Xanthomonas oryzae pv. oryzae (Xoo). This disease causes yield losses of more than $40 \%$ (Swamy et al., 2006). Bacillus methylotrophicus and B. subtilis were reported to be able to suppress Xoo by 50.29 and $57.86 \%$ (El-shakh et al., 2015). Isolation of endophytic bacteria as control of targeted plant diseases Bacillus sp. carried out by heating the suspension of endophytic bacteria for $30 \mathrm{~min}$ at a $80^{\circ} \mathrm{C}$. B. subtilis var. amyloloquefaciens (FZB 24) can inhibit Xoo in vitro and endophytic EPB 18, EPB 11, FZB 24 can stimulate rice plant growth, and significantly reduce the intensity of rice leaf blight disease up to 85-87\% (Nagendran et al., 2013).

The aim of this research was to collect the rice root endophytic bacterial isolates (RREB) which able to produce IAA, understand the effect of RREB application in stimulating rice plant growth and suppress bacterial leaf blight disease, and evaluate the potential of rice root endophytic bacteria for controlling bacterial leaf blight disease.

\section{MATERIALS AND METHODS}

Research Site. This research was conducted from March to September 2019 at the Screen House, Plant Protection Laboratory, and Agrohorti Laboratory of the Agriculture Faculty, Jenderal Soedirman University. The endophytic bacteria were isolated from Karangwangkal, Sumbang, Serayu, and Somagede Banyumas Regency, Central Java Province.

Isolation of Endophytic Bacteria. The experimental design used in the isolation and identification of endophytic bacteria was descriptive, starting with plants root sampling by purposive random sampling. The isolation was done by choose two healthy rice plants, took their roots, cleaned in running water, and weighed $100 \mathrm{~g}$ each. Rice root endophytic bacteria were isolated by sterilizing the root surface with sodium hypochlorite, then rinsed with sterile water 3 times, macerated with sterile porcelain mortal, and added $100 \mathrm{~mL}$ of sterile water. The $1 \mathrm{~mL}$ of suspension then added $9 \mathrm{~mL}$ of sterile water and incubated at $80{ }^{\circ} \mathrm{C}$ for $30 \mathrm{~min}$ for Bacillus sp. target (Singh et al., 2016). Five times serial dillution then carried out, the fourth and fifth dilutions were cultured on the NA (nutrient agar) medium with spread plate method. The growing colonies then observed the macroscopic and microscopic morphology.

Quantitative and Qualitative IAA Production Test. Each RREB isolate was grown on LB (Luria Bertani) medium with $40 \mathrm{~g} / \mathrm{mLL}$-Tryptophan added and incubated in a shaker in room temperature $29 \pm 1{ }^{\circ} \mathrm{C}$ at $150 \mathrm{rpm}$ for $48 \mathrm{~h}$. After that, it was centrifuged at $3000 \mathrm{rpm}$ for $15 \mathrm{~min}$. Subsequently, $1 \mathrm{~mL}$ of filtrate was mixed with $1 \mathrm{~mL}$ of Salkowski reagent $\left(1.5 \mathrm{~mL}\right.$ of $\mathrm{FeCl}_{3} \cdot 6 \mathrm{H}_{2} \mathrm{O}$ $0.5 \mathrm{M}$ in $80 \mathrm{~mL} \mathrm{H}_{2} \mathrm{SO}_{4} 60 \%$ solution), incubated at room temperature $29 \pm 1{ }^{\circ} \mathrm{C}$ for $30 \mathrm{~min}$. Qualitatively, IAA production was indicated by pink color, then IAA concentrations were measured quantitatively by a spectrophotometer with a wavelength of $550 \mathrm{~nm}$, compared to a predetermined IAA standard curve (Rana et al., 2011).

Experimental Design of RREB Application to the Growth of Rice Plants. The study was conducted using a randomized complete block design (RCBD) with treatments consisting of 8 RREB isolates and control (no RREB). Each treatment was repeated 3 times and each experimental unit contained 3 polybags. The rice used in this study was Ciherang variety. The treatments were B01 (Karangwangkal 7), B02 (Karangwangkal 5), B03 (Karangwangkal 8), B04 (Sumbang 1), B05 (Sumbang 2), B06 (Serayu 5), B07 (Serayu 7) and B08 (Somagede 1) and control (no isolate). The observed variables were plant height, leaf size, number of tillers, root length, root volume, fresh root weight, dry plant weight, and dry root weight.

Application of RREB to Suppress Bacterial Leaf Blight. The RREB was applied by soaking the seeds before seeding and spraying at 30 days after planting with RREB suspension $\left(10^{8} \mathrm{CFU} / \mathrm{mL}\right)$ and sterile water for control. Three plants were prepared for each treatment group and each plant was inoculated with Xoo suspension $\left(10^{8} \mathrm{CFU} / \mathrm{mL}\right)$ on the two leaves by leafclipping method using a sterile scissors that was dipped earlier in Xoo suspension (Singh et al., 2013). The disease intensity was calculated with formula (Suganda et al., 2016):

$$
\mathrm{DI}=\frac{\sum(\mathrm{n} \times \mathrm{v})}{\mathrm{Z} \times \mathrm{N}} \times 100 \%
$$

DI : disease intensity

$\mathrm{n}$ : number of infected plants for each score

$\mathrm{V}$ : infection score

$\mathrm{N}$ : number of observed plants

$\mathrm{Z}$ : maximum disease score 
The disease infection scores were: $0=$ no infection, $1=1-5$ squares $(4-20 \mathrm{~mm}), 2=6-10$ squares $(24-40$ $\mathrm{mm}), 3=11-15$ squares $(40-60 \mathrm{~mm}), 4=16-20$ squares $(64-80 \mathrm{~mm}), 5=21-25$ squares $(84-100 \mathrm{~mm})$.

The collected data were analyzed using analyses of variance (ANOVA and followed by DMRT (Duncan Multiple Range Test) on 5\% significance level.

\section{RESULTS AND DISCUSSION}

Isolation of Endophytic Bacteria. The macroscopic and microscopic characteristics of endophytic bacteria was presented in Table 1. All collected isolates were gram-positive bacteria with dominant rod shape (bacilli) cell and had endospore with malachite green staining. The colony were yellowish, white and creamy. The colony elevation is convex and flat (Figure 1). This result was in accordance with Nadeem et al. (2012) that bacterial colonies on the surface of the medium were vary in shapes, such as circular (round), irregular (round irregular) and also varies in elevation, such as flat, raised and convex.

Quantitative and Qualitative IAA Production Test. Qualitative test results was characterized by a change in the color of each endophytic bacterial suspension to pink reacted to Salkowski's reagent (Figure 2). This is in line with the opinion of Rahman et al. (2010), the pink discoloration of isolates after Salkowski's reagent drops was due to the reaction between Salkowski's reagent with IAA or with IAA-forming compounds. The observation result showed that isolate has the highest IAA production was B07 isolate, while the lowest production was B03 isolate (Table 2). The lowest IAA production isolates were originated from Karangwangkal area, it has more fertile land compared to marginal land, so that the potential of bacteria to be able to promote plant growth is lower. One of marginal land character was acidity due to the high level of total phosphate, however, some bacteria could solubilize phosphate and make it available for the plant. On marginal land, the limited nutrient content causing bacteria to be more active in producing IAA as a secondary metabolite that produced in extreme conditions. The bacteria as plant growth promoter capability produce IAA, the phosphate solubilizing ability, and siderophore secretion that chelates iron (Yu et al., 2011; Lwin et al., 2012). Kholida $\&$ Zulaika (2015) stated IAA is a major member of the auxin group which controls many important physiological processes including cell enlargement and division. IAA

Table 1. The morphological characteristics of RREB

\begin{tabular}{ccccccl}
\hline \multirow{2}{*}{ Isolates } & \multicolumn{2}{l}{ Microscopic morphology } & \multicolumn{5}{c}{ Macroscopic morphology } \\
& Size $(\mu \mathrm{m})$ & Gram test & Shape & Elevation & Margin & Color \\
\hline B01 & $2-3 \times 6-7$ & + & Rod & Flat & Undulate & White \\
B02 & $2-3 \times 6-7$ & + & Rod & Convex & Undulate & Yellow \\
B03 & $2-3 \times 6-7$ & + & Rod & Flat & Undulate & White \\
B04 & $2-3 \times 4-5$ & + & Rod & Flat & Undulate & White \\
B05 & $2-3 \times 6-7$ & + & Rod & Flat & Undulate & White \\
B06 & $2-3 \times 6-7$ & + & Rod & Convex & Entire & Yellow \\
B07 & $2-3 \times 6-7$ & + & Rod & Convex & Entire & White \\
B08 & $2-3 \times 6-7$ & + & Rod & Convex & Entire & Yellow \\
\hline
\end{tabular}

B01 (Karangwangkal 7), B02 (Karangwangkal 5), B03 (Karangwangkal 8), B04 (Sumbang 1), B05 (Sumbang 2), B06 (Serayu 5), B07 (Serayu 7), B08 (Somagede 1).
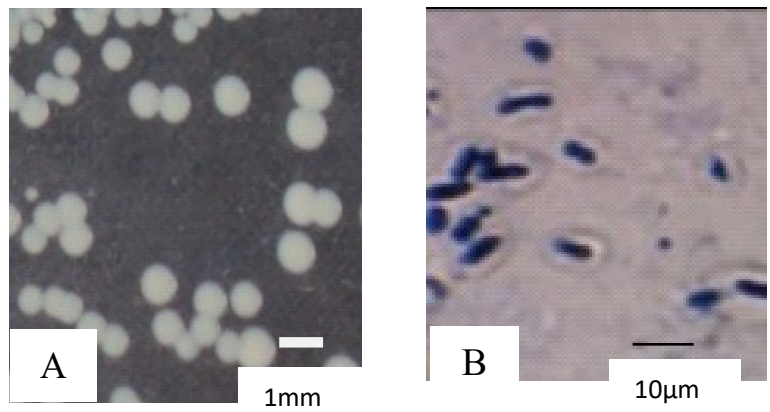

Figure 1. Rice root endophytes bacteria. (A) Colony, (B) Cells. 
stimulate plants to produce more lateral roots, root hairs and root hair branches (Rahman et al., 2010).

Effect of RREB Application to the Rice Plants Growth. The application of RREB significantly affected root length, root fresh weight, root volume, and root dry weight (Table 3). The application of bacterial isolates B04 and B07 showed an increase in root length of 39.96\% and $36.53 \%$, root volume of $82.72 \%$, root fresh weight of $79.37 \%$ and root dry weight with an increase of 52 , $13 \%$ (Table 3 ). This was presumably due to the IAA production as a growth hormone which causes faster root development and wider root surface so that nutrient uptake is increased followed by cell enlargement and root fresh weight will increase. Increased root fresh weight is mainly due to increased uptake of water. IAA produced by bacteria will be utilized by plants and will follow the metabolic processes in the plant so that it
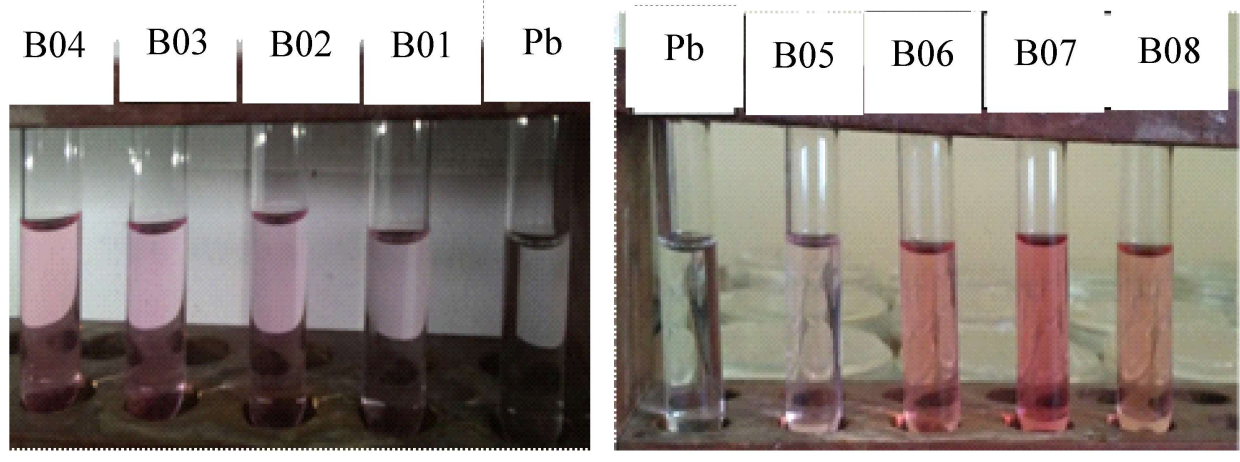

Figure 2. The IAA production test. $\mathrm{Pb}$ : control, B01-B08: endophytic bacteria isolates.

Table 2. IAA producing activity, quantitatively and qualitatively

\begin{tabular}{ccc}
\hline Isolates & Qualitative & Quantitative (ppm) \\
\hline B01 & + & 67.64 \\
B02 & + & 75.12 \\
B03 & + & 57.56 \\
B04 & + & 75.88 \\
B05 & + & 66.63 \\
B06 & + & 69.91 \\
B07 & + & 79.33 \\
B08 & + & 73.63 \\
\hline
\end{tabular}

B01 (Karangwangkal 7), B02 (Karangwangkal 5), B03 (Karangwangkal 8), B04 (Sumbang 1), B05 (Sumbang 2), B06 (Serayu 5), B07 (Serayu 7), B08 (Somagede 1).

Table 3. Application of RREB towards root length, root fresh weight, root volume, and root dry weight of ciherang paddy at 6 weeks after planting

\begin{tabular}{ccccc}
\hline Isolates & Root length $(\mathrm{cm})$ & Root volume $(\mathrm{mL})$ & Root fresh weight $(\mathrm{g})$ & Root dry weight $(\mathrm{g})$ \\
\hline Control & $3753.10 \mathrm{c}$ & $44.33 \mathrm{e}$ & $38.98 \mathrm{e}$ & $5.16 \mathrm{~cd}$ \\
B01 & $3636.55 \mathrm{~d}$ & $74.67 \mathrm{abc}$ & $62.01 \mathrm{~b}$ & $4.58 \mathrm{~d}$ \\
B02 & $3750.48 \mathrm{c}$ & $69.67 \mathrm{~cd}$ & $59.57 \mathrm{bc}$ & $5.75 \mathrm{c}$ \\
B03 & $3654.88 \mathrm{~d}$ & $67.33 \mathrm{~d}$ & $55.15 \mathrm{~cd}$ & $3.83 \mathrm{e}$ \\
B04 & $3876.19 \mathrm{a}$ & $81.00 \mathrm{a}$ & $69.29 \mathrm{a}$ & $7.85 \mathrm{a}$ \\
B05 & $3255.48 \mathrm{f}$ & $73.00 \mathrm{bcd}$ & $59.34 \mathrm{bc}$ & $5.77 \mathrm{c}$ \\
B06 & $2781.43 \mathrm{~g}$ & $71.67 \mathrm{bcd}$ & $52.87 \mathrm{~d}$ & $6.69 \mathrm{~b}$ \\
B07 & $3797.62 \mathrm{~b}$ & $75.00 \mathrm{abc}$ & $52.75 \mathrm{~d}$ & $4.66 \mathrm{~d}$ \\
B08 & $3496.43 \mathrm{e}$ & $78.00 \mathrm{ab}$ & $68.50 \mathrm{ab}$ & $4.92 \mathrm{~d}$ \\
\hline
\end{tabular}

Number followed by same letter in the same coloumn were not signifficantly different based on DMRT 5\%. B01 (Karangwangkal 7), B02 (Karangwangkal 5), B03 (Karangwangkal 8), B04 (Sumbang 1), B05 (Sumbang 2), B06 (Serayu 5), B07 (Serayu 7), B08 (Somagede 1). 
helps in the process of adding height, root volume, root length, and root fresh weight (Spaepen et al., 2007).

The analysis results from the observation of the number of tillers, plant height and leaf size was shown in Table 4. The application of B04 isolate showed the highest number of tillers (12.21 tillers) with an increase at 6.88 tillers or $129 \%$ relatives to control. The increase occurred due to the application of endophytic bacteria, so that nutrient needs were met in the process of photosynthesis at the age of 4 and 6 weeks after planting which included in the vegetative phase to form more rice tillers. According to Yoshida (1981), the number of tillers is strongly influenced by the availability of nitrogen and phosphorus in the soil. If enough nitrogen is found in the soil, plants can produce a large number of tillers, although not all of the growing tillers produce panicles. Based on the bi-weekly growth report above, the B04 treatment was the best in producing the number of tillers with the highest increase compared to the control treatment at 6 weeks after planting.
The B07 treatment was the best in increasing plant height with the highest increase at $10.28 \mathrm{~cm}$ or $14.39 \%$ relative to control. This showed that the association between endophytic bacterial isolates and their host plants was not only able to stimulate the formation of roots, but also can stimulate the height of rice plants.

The best treatment for increasing leaf size was B04 isolate with an increase in total leaf size at 1069.31 $\mathrm{cm}^{2}$ or $122.92 \%$ relative to control. Plant growth was increased by endophytic bacteria in the vegetative phase during cell division because it can stimulate plant growth by increasing leaf size. Ningrum et al. (2017) explained that, the higher consentration of PGPR, promote leaf surface area and vice versa. So that it can be in line with the application of endophytic bacteria.

Effect of RREB Application to Suppress Bacterial Leaf Blight. The bacterial leaf blight disease could be suppressed by application of RREB (Table 5). The best

Table 4. Application of RREB towards number of tillers, plant height and leaf size at 5 wap

\begin{tabular}{cccc}
\hline Isolates & Number of tillers & Plant height $(\mathrm{cm})$ & Leaf size $\left(\mathrm{cm}^{2}\right)$ \\
\hline Control & $5.33 \mathrm{~d}$ & $71.39 \mathrm{c}$ & $869.91 \mathrm{~g}$ \\
B01 & $10.58 \mathrm{~b}$ & $80.67 \mathrm{ab}$ & $1831.38 \mathrm{~b}$ \\
B02 & $10.24 \mathrm{~b}$ & $80.67 \mathrm{ab}$ & $1750.73 \mathrm{~cd}$ \\
B03 & $10.57 \mathrm{~b}$ & $80.44 \mathrm{ab}$ & $1809.24 \mathrm{bc}$ \\
B04 & $12.21 \mathrm{a}$ & $80.33 \mathrm{ab}$ & $1939.22 \mathrm{a}$ \\
B05 & $9.11 \mathrm{c}$ & $79.17 \mathrm{~b}$ & $1724.26 \mathrm{~d}$ \\
B06 & $9.00 \mathrm{c}$ & $81.11 \mathrm{a}$ & $1684.63 \mathrm{e}$ \\
B07 & $10.56 \mathrm{~b}$ & $81.67 \mathrm{a}$ & $1514.03 \mathrm{e}$ \\
B08 & $10.67 \mathrm{~b}$ & $81.22 \mathrm{a}$ & $1260.45 \mathrm{f}$ \\
\hline
\end{tabular}

Number followed by same letter in the same coloumn were not signifficantly different based on DMRT 5\%. B01 (Karangwangkal 7), B02 (Karangwangkal 5), B03 (Karangwangkal 8), B04 (Sumbang 1), B05 (Sumbang 2), B06 (Serayu 5), B07 (Serayu 7), B08 (Somagede 1).

Table 5. Phatosystem component of bacterial leaf blight disease on the application of RREB

\begin{tabular}{cccc}
\hline Isolates & Incubation period (dai) & Disease intensity (\%) & Effectiveness (\%) \\
\hline Control & 4.2 & $36.44 \mathrm{c}$ & - \\
B01 & 5.8 & $18.67 \mathrm{ab}$ & 48.76 \\
B02 & 4.8 & $20.22 \mathrm{~b}$ & 44.51 \\
B03 & 5.7 & $13.78 \mathrm{ab}$ & 62.18 \\
B04 & 6.1 & $11.56 \mathrm{a}$ & 68.27 \\
B05 & 5.8 & $15.78 \mathrm{ab}$ & 56.69 \\
B06 & 5.8 & $14.22 \mathrm{ab}$ & 60.98 \\
B07 & 5.6 & $13.11 \mathrm{ab}$ & 64.02 \\
B08 & 6.1 & $21.11 \mathrm{~b}$ & 42.06 \\
\hline
\end{tabular}

Number followed by same letter in the same coloumn were not signifficantly different based on DMRT 5\%. dai = day after inoculation. B01 (Karangwangkal 7), B02 (Karangwangkal 5), B03 (Karangwangkal 8), B04 (Sumbang 1), B05 (Sumbang 2), B06 (Serayu 5), B07 (Serayu 7), B08 (Somagede 1). 
was isolates collected from Sumbang, with an effective disease suppression of $68.27 \%$ compared to control. This was due to the isolates collected from non-suboptimal or marginal land with adequate water conditions, and obtained from healthy plants among diseased plants. These conditions indicate the suitability for the growth of antagonistic bacteria because of adequate nutrition, so that it has the potential as a biological control agent and promoter of plant growth. Moustaine et al. (2017) suggested that, the rhizosphere and endophytes bacteria associated with the roots, are able to benefit plants which are shown by their ability to produce plant hormones such as auxin, N2 fixation, and phosphate solubilizer. In addition, it was also stated that endophytic bacteria and rhizosphere as antagonists to pathogens by producing antibiotics, siderophore, chitinase and other nutrients that are able to effectively colonize the roots as a trigger for plant growth.

\section{CONCLUSION}

In total, 8 isolates of root endophyte bacteria was collected from paddy roots. The isolates could produce IAA up to $79.33 \mathrm{ppm}$, among others the B07 isolate produce highest amount of IAA. The B04 isolate from Sumbang and B07 from Serayu was able to promote the paddy growth. The application of endophytic bacteria could effectively control the bacterial leaf blight.

\section{ACKNOWLEDGMENT}

The authors wish to thank DRPM for the funds that have been provided to support applied research activities in 2019.

\section{REFERENCES}

Badan Pusat Statistik (BPS). 2019. Kajian Konsumsi dan Cadangan Beras Nasional 2017. Badan Pusat Statistik. Jakarta.

Cahyaty RAA, Aini N, \& Sumarni T. 2017. Pengaruh salinitas dan aplikasi bakteri rhizosfer toleran salin terhadap komponen hasil tanaman mentimun. Jurnal Biotropika. 3(5): 133-137.

El-shakh ASA, Kakar KU, Wang X, Almoneafy AA, Ojaghian MR, Li B, Anjum SI, \& Xie GL. 2015 Controlling bacterial leaf blight of rice and enhancing the plant growth with endophytic and rhizobacterial Bacillus strains. Toxicol. Environ. Chem. 97(6): 766-785.
Hallmann J. 2001. Plant interactions with endophytic bacteria. In: Jeger MJ \& Spence NJ (eds.). Biotic Interactions in Plant-Pathogen Associations. pp. 87-119. CAB International, Wallingford.

Havlin JL, Tisdale SL, Beaton JD, \& Nelson WL. 2005. Soil Fertility and Fertilizers: an Introduction to Nutrient Management. Pearson Education/ Prentice-Hall, Inc.. Upper Saddle River, New Jersey.

Kasno A. 2010. Nutrient balance at integrated nutrient management on lowland rice which is dominated by 1:1 clay mineral for high potential rice yields. J. Trop. Soils. 15(2): 119-126.

Khalid A, Arshad M, \& Zahir ZA. 2004. Screening plant growth-promoting rhizobacteria for improving growth and yield of wheat. J. Appl. Microbiol. 96(3): 473-480.

Kholida FT \& Zulaika E. 2015. Potensi Azotobacter sebagai penghasil hormon IAA (Indole-3-Acetic Acid). Jurnal Sains dan Seni ITS. 4(2): E75.

Kloepper JW, Rodriguez-Kabana R, McInroy JA, \& Young RW. 1992. Rhizosphere bacteria antagonistic to soybean cyst (Heterodera glycines) and root-knot (Meloidogyne incognita) nematodes: identification by fatty acid analysis and frequency of biological control activity. Plant and Soil. 139: 75-84.

Lwin KM, Myint MM, Tar T, \& Aung WZM. 2012. Isolation of plant hormone (indole-3-acetic acidIAA) producing rhizobacteria and study on their effects on maize seedling. Engineering Journal. 16(5): 137-144.

Moustaine M, Elkahkahi R, Benbouazza A, Benkirane R, \& Achbani EH. 2017. Effect of plant growth promoting rhizobacterial (PGPR) inoculation on growth in tomato (Solanum Lycopersicum L.) and characterization for direct PGP abilities in Morocco. IJEAB. 2(2): 590-596.

Nadeem SM, Shaharoona B, Arshad M, \& Crowley DE. 2012. Population density and functional diversity of plant growth promoting rhizobacteria associated with avocado trees in saline soils. Appl. Soil Ecol. 62: 147-154.

Nagendran K, Karthikeyan G, Peeran MF, Raveendran M, Prabakar K, \& Raguchander T. 2013. Management of bacterial leaf blight disease in rice with endophytic bacteria. World Appl. Sci. J. 28(12): 2229-2241. 
Ningrum WA, Wicaksono KP, \& Tyasmoro SY. 2017. Pengaruh plant growth promoting rhizobacteria (PGPR) dan pupuk kandang kelinci terhadap pertumbuhan dan produksi tanaman jagung manis (Zea mays Saccharata). Jurnal Produksi Tanaman. 5(3): 433-440.

Patil V. 2011. Production of indole acetic acid by Azotobacter sp. Recent. Res. Sci. Technol. 3(12): 14-16.

Rahman A, Sitepu IR, Tang SY, \& Hashidoko Y. 2010. Salkowski's reagent test as a primary screening index for functionalities of rhizobacteria isolated from wild dipterocarp saplings growing naturally on medium-strongly acidic tropical peat soil. Biosci. Biotechnol. Biochem. 74(11): 22022208.

Rana A, Saharan B, Joshi M, Prasanna R, Kumar K, \& Nain L. 2011. Identification of multi-trait PGPR isolates and evaluating their potential as inoculants for wheat. Ann. Microbiol. 61(4): 893-900.

Setiawati MR, Arief DH, Suryatmana P, \& Hudaya R. 2008. Aplikasi bakteri endofitik penambat N2 untuk meningkatkan populasi bakteri endofitik dan hasil tanaman padi sawah. Jurnal Agrikultura. 19(3): 13-19.

Setiawati MR, Hindersah R, \& Fitriatin BN. 2002. Penggalian potensi bakteri endofitik pemfiksasi $\mathrm{N}$ dalam meningkatkan fiksasi dan serapan $\mathrm{N}$ tanaman padi gogo. Laporan Penelitian. Universitas Padjajaran, Bandung.

Singh AK, Singh PK, Sarma BK, \& Nandan R. 2013. Comparison of methods of inoculation of Xanthomonas oryzae pv. oryzae in rice (Oryza sativa L.). Bioinfolet. 10(2A): 364-366.
Singh D, Yadav DK, Chaudhary G, Rana VS, \& Sharma RK. 2016. Potential of Bacillus amyloliquefaciens for biocontrol of bacterial wilt of tomato incited by Ralstonia solanacearum. J. Plant Pathol. Microbiol. 7(1): 327.

Spaepen S, Vabderleyden J, \& Remans R. 2007. Indole3-acetic acid in microbial and microorganism-plant signaling. FEMS Microbiol. Rev. 31(4): 425-448.

Suganda T, Yulia E, Widiantini F, \& Hersanti. 2016. Intensitas penyakit blas (Pyricularia oryzae Cav.) pada padi varietas ciherang di lokasi endemik dan pengaruhnya terhadap kehilangan hasil. Jurnal Agrikultura. 27(3): 154-159.

Swamy P, Panchbhai AN, Dodiya P, Naik V, Panchbhai SD, Zehr UB, Azhakanandam K, \& Char BR. 2006. Evaluation of bacterial blight resistance in rice lines carrying multiple resistance genes and Xa21 transgenic lines. Curr. Sci. 90(6): 818-824.

Wozniak M, Galazka A, Tyskiewicz R, \& JaroszukScisel J. 2019. Endophytic Bacteria Potentially Promote Plant Growth by Synthesizing Different Metabolites and their Phenotypic/Physiological Profiles in the Biolog GEN III MicroPlateTM Test. Int. J. Mol. Sci. 20(21): 5283.

Yoshida S. 1981. Fundamentals of Rice Crop Science. International Rice Research Institute, Los Banos.

Yu X, Liu X, Zhu TH, Liu GH, \& Mao C. 2011. Isolation and characterization of phosphate-solubilizing bacteria from walnut and their effect on growth and phosphorus mobilization. Biol. Fert. Soils 47(4): 437-446. 